\title{
Legal Atlantic Forest (Mata Atlântica Legal): integrating biogeography to public policies towards the conservation of the biodiversity hotspot
}

\author{
Mata Atlântica Legal: integrando as visões da biogeografia \\ às políticas públicas para conservação de um hotspot \\ de biodiversidade
}

André de Almeida Cunha ${ }^{a}$

Carla Bernadete Madureira Cruz ${ }^{\mathrm{b}}$

Gustavo Alberto Bouchardet da Fonseca ${ }^{c}$

${ }^{a}$ Professor Adjunto do Departamento de Ecologia, pesquisador do Centro de Excelência em Turismo - CET e do Centro de Estudos do Cerrado, Universidade de Brasília, Brasilia, DF, Brasil

End. Eletrônico: cunha.andre@gmail.com

${ }^{b}$ Professora Titular do Departamento de Geografia, Coordenadora do Laboratório Espaço de Sensoriamento Remoto e Estudos Ambientais, Universidade Federal do Rio de Janeiro,

Rio de Janeiro, RJ, Brasil

End. Eletrônico: carlamad@gmail.com

'Professor titular do Departamento de Zoologia, Instituto de Ciências Biológicas, Universidade Federal de Minas Gerais, Belo Horizonte, MG, Brasil

End. Eletrônico: gfonseca1@thegef.org

doi:10.18472/SustDeb.v10n3.2019.27112

Received: 10/09/2019

\begin{abstract}
The Atlantic Forest (AF) is one of the most biodiverse and threatened biomes on the planet, but the existence of two official boundaries (AF Biome and Domain - AF Law) causes uncertainties, with consequences for public policies and the conservation of remnants. In order to understand the biogeography and its influence for protection of the AF, the areas of the two boundaries and the overlap with states and ecoregions they occupy were compared. Our results, supported by the literature, indicate that the Legal boundary is broader and more representative of AF's current and
\end{abstract}


evolutionary heterogeneity and diversity, and provides a more adequate legal basis for its conservation and sustainable use, especially in the northeast region, where the biggest difference between both limits were encountered. Thus, the term Legal Atlantic Forest should be increasingly used, in order to reinforce the full application of laws governing the protection and sustainable use of the biome.

Keywords: Biome. Atlantic Forest Dominion. Ecoregion. Protected Areas. Remnants. Climate.

\section{RESUMO}

A Mata Atlântica (MA) é um dos biomas mais biodiversos e ameaçados do planeta, mas a existência de dois limites oficiais (Bioma e Domínio - Lei da MA) suscita dúvidas e incertezas, com consequências para a aplicação de políticas públicas e a conservação dos remanescentes. Visando compreender a biogeografia e seus desdobramentos para a proteção da MA, foram comparadas as áreas dos dois limites, e a sobreposição com as unidades da federação e ecorregiões que ocupam. Nossos resultados, apoiados pela literatura, indicam que o limite Legal é mais abrangente e representativo da heterogeneidade e diversidade atual e evolutiva da $M A$, e proporciona uma base legal mais adequada para sua conservação e uso sustentável, principalmente na região nordeste, onde há a maior diferença entre os limites. Logo, o termo Mata Atlântica Legal deve ser amplamente difundido, visando reforçar a aplicação integral das leis que governam a proteção e uso sustentável do bioma.

Palavras-Chave: Bioma. Domínio Mata Atlântica. Ecorregião. Áreas Protegidas. Remanescentes. Clima.

\section{INTRODUCTION}

The Atlantic Forest is known as one of the regions with the highest species richness and endemism, as well as one of the most endangered forests on the planet, a biodiversity hotspot. (MYERS et al., 2000; MITTERMEIER et al., 2004). The conservation of scarce remnants depends on the engagement of different sectors of society, as well as effective public policies (CUNHA; GUEDES, 2013; REZENDE et al, 2018). The term Atlantic Forest is widely used and accepted, but its scientific meaning still needs to be better understood (CÂMARA, 2003). The biota of a given region is the result of a group of species overlapping different evolutionary histories (BROWN, 2004). The rich biodiversity of the Atlantic Forest is the result of a complex biogeographic history, influenced by processes such as Pleistocene glaciations, montane refuges and ecological gradients (LARA et al., 2005), in constant interaction with surrounding biomes. This context makes it difficult to define precisely the biogeographic and geopolitical boundaries.

There are two official limits to the Brazilian Atlantic Forest: the Atlantic Forest Biome (BRAZIL, 2004a) and the Atlantic Forest Law enforcement area (BRAZIL, 2008), also known as the Atlantic Forest Domain. Both boundaries were elaborated with the support of dozens of researchers and managers, seeking a biogeographic understanding and a basis for the application of public policies. Historically, several authors have proposed divisions for Brazil's phytophysiognomies or ecological complexes, but few have cited the term Atlantic Forest (IBGE, 2012) as currently adopted (Table 1). Ab'Saber, for example, in 1965 , suggested two "morphoclimatic domains", as well as an extensive "mixed and complex contact and transition zone" between the Atlantic and Araucaria Forests with Cerrados and Caatinga (Box 1) (AB'SABER, 2003). In the recent definition of ecoregions (OLSON et al. 2001), on a finer scale, the Atlantic Forest encompasses 12 ecoregions, as well as portions of the Caatinga, Cerrado, and Uruguayan Savannas (Figure 1, Table 1). Subsequently, based on vertebrate endemisms, it was proposed to group and subdivide them into eight bioregions (SILVA; CASTELETTI, 2003), in the Atlantic Forest Domain (BRAZIL, 2008). The debate about biota composition, phytophysiognomic and biogeographic patterns, and the evolutionary processes of the Atlantic Forest is extremely exciting. However, considering the advanced state of habitat and biodiversity loss, consistent public policies and actions are urgent, to seek the preservation and restoration of the remnants of this hotspot. 
Box 1 | Classification of Atlantic Forest Brazilian Sub-Regions proposed in the 20th century.

\begin{tabular}{|c|c|c|c|}
\hline $\begin{array}{c}\text { Brazilian Morphoclimatic } \\
\text { Domains }\end{array}$ & South American Forests & $\begin{array}{l}\text { Phytogeography } \\
\text { Treaty of Brazil }\end{array}$ & Ecoregions \\
\hline Ab’Saber (1965) & Hueck (1972) & Rizzini (1979) & Olson et al. (2001) \\
\hline \multirow{7}{*}{$\begin{array}{l}\text { Mamelonares Forested } \\
\text { Areas or Tropical } \\
\text { Atlantic Domain }\end{array}$} & \multirow{5}{*}{ Brazil's coastal rainforest } & \multirow{7}{*}{ Atlantic Forest } & Bahia Coastal Forest \\
\hline & & & Bahia Interior Forest \\
\hline & & & Pernambuco Coastal Forest \\
\hline & & & Pernambuco Interior Forest \\
\hline & & & \\
\hline & \multirow{2}{*}{\begin{tabular}{|c} 
Region of the \\
subtropical forests of \\
eastern and southern \\
Brazil
\end{tabular}} & & Serra do Mar Coastal Forest \\
\hline & & & Upper Paraná Atlantic Forest \\
\hline \multirow[t]{3}{*}{$\begin{array}{l}\text { Subtropical Plateaus } \\
\text { with Araucaria }\end{array}$} & $\begin{array}{l}\text { Araucaria Forest Region } \\
\text { of Southern Brazil }\end{array}$ & Pinewood & Araucaria Rainforest \\
\hline & \multirow{2}{*}{ Coastal Region of Brazil } & Restingas & Atlantic Coast Restinga \\
\hline & & & South Atlantic Mangroves \\
\hline \multirow{3}{*}{$\begin{array}{l}\text { Undifferentiated } \\
\text { Transition Zones }\end{array}$} & & & Atlantic Dry Forest \\
\hline & & & Caatinga Enclaves Rainforest \\
\hline & & & Savannah Montana Rupestres Fields \\
\hline
\end{tabular}

Source: Study data.

Currently, between $12 \%$ and $16 \%$ of the total territory of the Atlantic Forest Domain (RIBEIRO et al., 2009 ) or, depending on the study, from $22 \%$ to $28 \%$ of the Atlantic Forest Biome (CRUZ; VICENS, 2007; REZENDE et al., 2018) have remnants similar to the original or historical coverage, European precolonization. Although extremely fragmented and degraded (RIBEIRO et al., 2009), they still support high species richness (FONSECA et al., 2009; PARDINI et al., 2009; VIEIRA et al., 2009).

Conservation units cover about $10 \%$ of the biome, but less than $2.6 \%$ is under strictly protection (Cadastro Nacional de Áreas Protegidas, 2019), and large vertebrate populations are no longer viable in most landscapes (GALETTI et al. al., 2009), with several local extinctions already recorded (CUNHA, 2004; CANALE et al., 2012). If the landscape is not managed properly and effectively (METZGER et al., 2009), the extinction debt will soon show its effects, leading to the loss of several species (BROOKS et al., 2002). Therefore, decision-making and nature conservation in practice need pragmatic definitions, including geographical delimitation for the implementation of public policies.

Aiming to understand the biogeography to address public policies consistently, we compared the two geopolitical limits for the Atlantic Forest (Biome vs Domain) and the divergent areas between them. We analyzed: (1) the geographic range and the overlap of the two limits of the Atlantic Forest with ecoregions (Olson et al., 2001), and with states (UF) and regions of the country (South, Southeast, Northeast and Midwest); and (2) the biota composition and biogeographic relationships in areas of divergence between the two limits. Finally, results were considered for the consequences for the decision-making, public policy and conservation, in practice, of the remaining Atlantic Forest. 


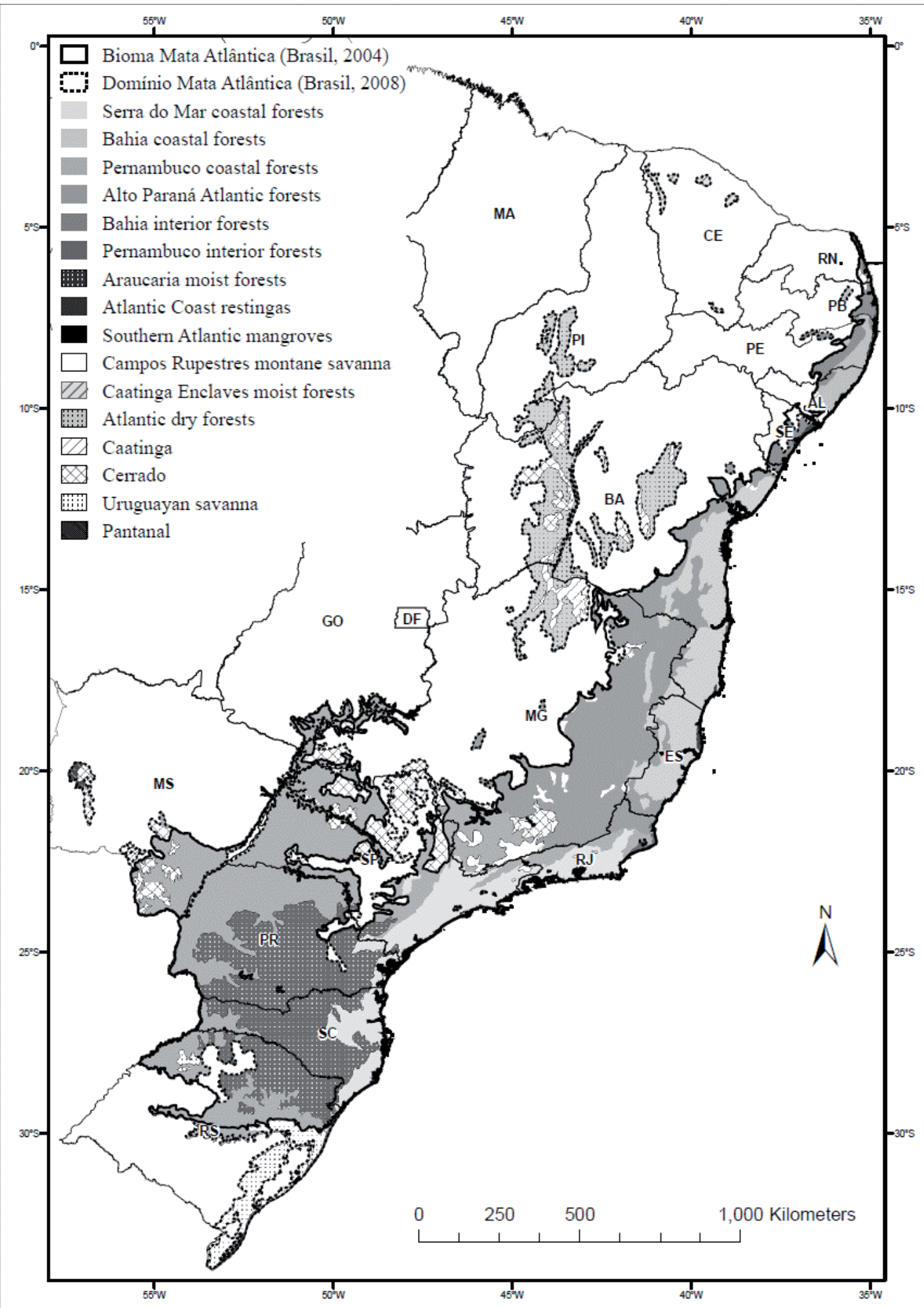

Figure 1 | Boundaries of the Atlantic Forest in Brazilian territory. The dashed line represents the Atlantic Forest Domain, or Legal Atlantic Forest (BRAZIL, 2008) and the solid line delimits the Atlantic Forest Biome (BRAZIL, 2004b). The shades of gray represent the covered ecoregions, with the original denomination in English (OLSON et al., 2001). 


\section{METHODS}

The geographic range and the divergent areas between the boundaries of the Atlantic Forest Biome (BRAZIL, 2004a) and the Map of the Atlantic Forest Law Enforcement Area (BRAZIL, 2008), also known as the Atlantic Forest Domain, were analyzed in geographic information systems. Both limits were elaborated by the Brazilian Institute of Geography and Statistics (Instituto Brasileiro de Geografia e Estatística - IBGE) from the Vegetation Map of Brazil (BRASIL 1993; 2004b).

The difference between these two boundaries is that they encompass different portions of deciduous and semi-deciduous forests in central and northeastern Brazil (Figure 1). This is justified based on the composition and biogeography of some species, mostly birds and mammals (SILVA; CATELETTI, 2003). The shape-files of these boundaries were superimposed on the polygons of the ecoregions (OLSON et al., 2001), and of the federative units (states - FU) and Regions (Northeast, Southeast, Midwest and South) of Brazil, using the intersect tool of the ArcGis 9.0 software, and standardized for the projection system (latitude and longitude) and the geodetic system (SIRGAS 2000).

The resulting areas were calculated with the "Albers equivalent" projection (ORMSBY et al., 2004). Were accounted (i) the absolute area ( $\mathrm{km} 2$ ) of the ecoregions and states (FUs) covered by each of the two limits proposed for the Atlantic Forest, Domain and Biome, (ii) the percentage of the area of each FU and each ecoregion occupied by each of the Atlantic Forest boundaries, and (iii) how much this area represents of the total area of the Atlantic Forest Domain and Biome (Tables 1 and 2).

To subsidize the biogeographic considerations about the composition of the biota in the divergent areas between the boundary of the Domain, or legal area of the Atlantic Forest, and the Biome, bibliographical references already published on the subject were consulted. The majority are vertebrate inventories, but also reviews of woody plant inventories, and a few works for other taxon (see discussion). These inventories are of particular taxon, with different sample designs, collection techniques and capture efforts. Thus, we chose to analyze the biota composition in the divergent areas between the two boundaries and their relationship with the surrounding biomes, based on the authors' arguments of these inventories. The classification of species as endemic followed exclusively that one adopted in the studies consulted, even when the definition of Atlantic Forest or endemism assumed by each one was not explicit.

Thus, we compare the range of the two proposed limits for the Brazilian Atlantic Forest, Domain (BRASIL, 2008) vs. Biome (BRAZIL, 2004a), considering the biota composition and the biogeography, and then we consider the implications for the conservation of the Atlantic Forest remnants, when considering these two distinct limits.

\section{RESULTS}

The boundaries of the Atlantic Forest Biome and Domain overlap most of their extensions (Figure 1). However, the area of the Atlantic Forest Law (Domain) (BRAZIL, 2008) is 235,000 km2, about $25 \%$ larger than the area occupied by the Biome (BRAZIL, 2004a). Of this difference, $118,000 \mathrm{~km} 2$ $(50 \%)$ are in the Northeast, $80,000 \mathrm{~km} 2(34 \%)$ in the Southeast, $30,000 \mathrm{~km} 2(13 \%)$ in Southern Brazil, and 8,000 km2 (3\%) in Mato Grosso do Sul (MS) in the Midwest (Figure 1, Table 1). The Domain covers all states in the South, Southeast and Northeast (except Maranhão), as well as MS and Goiás, in the Midwest. The Biome encompasses the same states except Ceará and Piauí in the Northeast (Figures 1 and 2). 
Table 1 | Extension of the Atlantic Forest in the Federative Units - FU, or states, of Brazil, according to the limits of the Legal Atlantic Forest (Atlantic Forest Law Enforcement Area, or Domain) (BRAZIL, 2008) and the Atlantic Forest Biome (BRAZIL, 2004a).

\begin{tabular}{|c|c|c|c|c|}
\hline Region & $F U$ & $\begin{array}{l}\text { Legal Atlantic Forest } \\
\text { (Brasil, 2008) }\end{array}$ & $\begin{array}{l}\text { Atlantic Forest Biome } \\
\text { (Brasil, 2004a })^{\pi}\end{array}$ & $\begin{array}{c}\text { Diference } \\
\text { (Legal MA-Biome) }\end{array}$ \\
\hline \multirow{9}{*}{$\begin{array}{l}\text { Nordeste } \\
\text { (Northeast) }\end{array}$} & $\mathrm{PI}$ & $\begin{array}{c}22.822 \\
(1,7 / 9,1)\end{array}$ & - & 22.822 \\
\hline & CE & $\begin{array}{c}4.845 \\
(0,4 / 3,3)\end{array}$ & - & 4.845 \\
\hline & $\mathrm{RN}$ & $\begin{array}{c}3.271 \\
(0,2 / 6,2)\end{array}$ & $\begin{array}{c}2.848 \\
(0,3 / 5,4)\end{array}$ & 423 \\
\hline & PB & $\begin{array}{c}6.697 \\
(0,5 / 11,9)\end{array}$ & $\begin{array}{c}5.058 \\
(0,4 / 9,0)\end{array}$ & 1.639 \\
\hline & $P E$ & $\begin{array}{c}17.713 \\
(1,3 / 18,0)\end{array}$ & $\begin{array}{c}17.093 \\
(1,5 / 18,0)\end{array}$ & 620 \\
\hline & $\mathrm{AL}$ & $\begin{array}{c}14.410 \\
(1,1 / 51,9)\end{array}$ & $\begin{array}{c}14.707 \\
(1,3 / 52,9)\end{array}$ & -297 \\
\hline & SE & $\begin{array}{c}7.856 \\
(0,6 / 35,9)\end{array}$ & $\begin{array}{c}11.796 \\
(1,1 / 53,9)\end{array}$ & -3.940 \\
\hline & BA & $\begin{array}{c}203.176 \\
(15,1 / 36,0)\end{array}$ & $\begin{array}{c}111.077 \\
(10,0 / 19,7)\end{array}$ & 92.099 \\
\hline & Total NE* & $\begin{array}{c}280.791 \\
(20,8 / 23,0)\end{array}$ & $\begin{array}{c}162.578 \\
(14,6 / 13,3)\end{array}$ & 118.213 \\
\hline \multirow{3}{*}{$\begin{array}{l}\text { Centro-Oeste } \\
\text { (Mid-West) }\end{array}$} & GO & $\begin{array}{c}10.649 \\
(0,8 / 3,1)\end{array}$ & $\begin{array}{c}10.513 \\
(0,9 / 3,1)\end{array}$ & 136 \\
\hline & MS & $\begin{array}{c}57.910 \\
(4,3 / 16,2)\end{array}$ & $\begin{array}{c}50.397 \\
(4,5 / 14,1)\end{array}$ & 7.513 \\
\hline & Total CO* & $\begin{array}{c}68.559 \\
(5,1 / 9,8)\end{array}$ & $\begin{array}{c}60.910 \\
(5,5 / 8,7)\end{array}$ & 7.649 \\
\hline \multirow{5}{*}{$\begin{array}{l}\text { Sudeste } \\
\text { (Southeast) }\end{array}$} & MG & $\begin{array}{c}287.329 \\
(21,3 / 49,0)\end{array}$ & $\begin{array}{c}241.718 \\
(21,7 / 41,2)\end{array}$ & 45.611 \\
\hline & ES & $\begin{array}{c}46.030 \\
(3,4 / 99,9)\end{array}$ & $\begin{array}{c}45.945 \\
(4,1 / 99,7)\end{array}$ & 85 \\
\hline & RJ & $\begin{array}{c}43.550 \\
(3,4 / 99,9)\end{array}$ & $\begin{array}{c}43.626 \\
(3,9 / 99,8)\end{array}$ & -76 \\
\hline & SP & $\begin{array}{c}201.352 \\
(14,9 / 81,1)\end{array}$ & $\begin{array}{c}166.889 \\
(15,0 / 67,2)\end{array}$ & 34.463 \\
\hline & Total SE & $\begin{array}{c}578.261 \\
(42,9 / 62,5)\end{array}$ & $\begin{array}{c}498.178 \\
(44,7 / 53,8)\end{array}$ & 80.083 \\
\hline \multirow{5}{*}{$\begin{array}{l}\text { Sul } \\
\text { (South) }\end{array}$} & PR & $\begin{array}{c}193.555 \\
(14,3 / 97,1)\end{array}$ & $\begin{array}{c}194.386 \\
(17,4 / 97,5)\end{array}$ & -831 \\
\hline & SC & $\begin{array}{c}95.227 \\
(7,1 / 99,9)\end{array}$ & $\begin{array}{c}94.674 \\
(8,5 / 99,2)\end{array}$ & 553 \\
\hline & RS & $\begin{array}{c}132.662 \\
(9,8 / 47,1)\end{array}$ & $\begin{array}{c}102.931 \\
(9,2 / 36,5)\end{array}$ & 29.731 \\
\hline & Total Sul & $\begin{array}{c}421.443 \\
(31,2 / 73,1)\end{array}$ & $\begin{array}{c}391.991 \\
(35,2 / 68,0)\end{array}$ & 29.452 \\
\hline & Total & 1.349 .055 & 1.113 .657 & 235.398 \\
\hline
\end{tabular}

The numbers indicate the absolute area $(\mathrm{km} 2)$ of the Atlantic Forest in each state, and contained in brackets (i) the percentage of Atlantic Forest found in the FU / and (ii) the percentage of FU in the Atlantic Forest.

*The total amounts for the Northeast and Midwest accounted only the FU listed area.

Source: Study data. 
In both limits, the largest fraction of the Atlantic Forest is in the Southeast region, $43 \%$ vs. $45 \%$ of the total area of the Domain and Biome, respectively. Followed by the South region 31\% vs. 35\%, Northeast 21\% vs. $15 \%$, and in the Midwest 5.1\% vs. 5.5\%. The states of Minas Gerais (MG), Paraná (PR), São Paulo (SP), Bahia (BA), Rio Grande do Sul (RS), Santa Catarina (SC), Mato Grosso do Sul (MS), Espírito Santo (ES) and Rio de Janeiro (RJ) encompass the largest absolute areas, both in the Domain and in the Biome (Table 1).

Some states are fully inserted in the Atlantic Forest, considering both limits, such as ES, RJ, SC and PR. Between $1 / 3$ and $2 / 3$ of the states of SP, MG, RS, Sergipe (SE) and Alagoas (AL) are in the Atlantic Forest (Table 1). Above all, the area covered by the two boundaries differs markedly in the states of SE, BA, SP and RS, there are less significant differences in MG, Paraíba (PB) and MS. The Piauí and Ceará Atlantic Forest is recognized only by the limit of the law (Domain), but not by the Biome (Table 1, Figures 1 and 2 ).

The Domain boundary encompasses more than 99\% of the Biome area (Brazil, 2004a), and extends beyond to the São Francisco dry forests (MG, BA, and PI); the Chapada Diamantina region (BA); the Northeast Enclave Forests (PI, CE, RN, PB, and PE); the Serra da Bodoquena (MS); and part of the Uruguayan Savannas and forests of RS, as well as areas of the Cerrado, in SP and MG. The Biome boundary includes, in addition to the Domain, areas of SE, AL, PB, and RN, and small portions of MG and SP not included in the Domain boundary (Figures 1 and 2), although this represents only $1 \%$ of the Biome area.

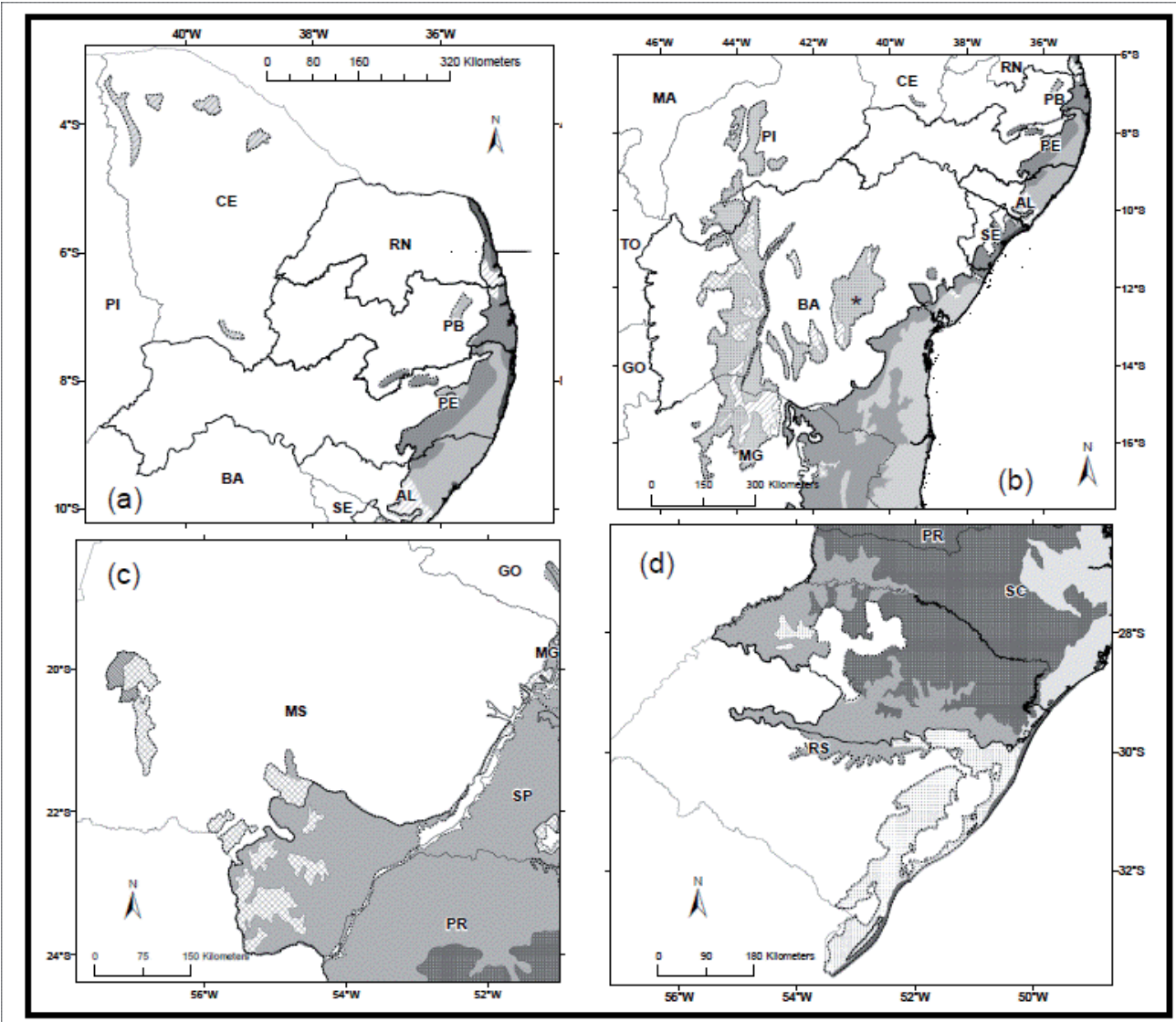

Figure 2 - Divergent areas between the limits of the Atlantic Forest in the Brazilian territory: (a) Northeastern Enclave Forests, in Ceará, covering the Caatinga Enclaves Rainforest ecoregion, and in northern Paraíba, the

Pernambuco Coastal Forest in southern Paraíba and Pernambuco, the Pernambuco Inland Forest. (b) São Francisco and Chapada Diamantina Dried Forests (highlighted with an asterisk), mostly occupied by the Atlantic Dry Forest ecoregion, and smaller portions of the Cerrado and Caatinga. (c) Serra da Bodoquena, encompassing the Cerrado and Pantanal; and (d) Southern Rio Grande do Sul Forests, and around Patos Lagoon, in the Upper Paraná and Uruguayan Savannah ecoregions, respectively. For subtitles, see Figure 1. 
The Atlantic Forest Domain includes 15 ecoregions, two in addition to the Biome (Figure 1): the Atlantic Dry Forest, or São Francisco Dry Forests (108,000 km2); and the Caatinga Enclaves Rainforest, or Northeastern Enclaves $(4,4000 \mathrm{~km} 2)$, as well as larger portions of the Cerrado ecoregions $(+67,000$ $\mathrm{km} 2)$, Caatinga $(+15,000 \mathrm{~km} 2)$ and Savannah Uruguayan $(+20,000 \mathrm{~km} 2)$ (Figure 2 and Table 2).

Table 2: Extension of Atlantic Forest ecoregions within the limits of the Legal Atlantic Forest (Brazil, 2008) and the Atlantic Forest Biome (Brazil, 2004a).

\begin{tabular}{|c|c|c|}
\hline Ecorregion (Olson et al, 2001) & Legal Atlantic Forest* & Biome* \\
\hline Alto Paraná Atlantic forest & $\begin{array}{c}340.127 \\
(25,2 / 74,1) \\
\end{array}$ & $\begin{array}{c}336.353 \\
(30,2 / 73,3)\end{array}$ \\
\hline Bahia interior forest & $\begin{array}{c}224.104 \\
(16,6 / 97,8)\end{array}$ & $\begin{array}{c}220.966 \\
(19,8 / 96,4)\end{array}$ \\
\hline Araucária Moist Forest & $\begin{array}{c}210.617 \\
(15,6 / 97,7)\end{array}$ & $\begin{array}{c}211.044 \\
(19,0 / 97,9)\end{array}$ \\
\hline Bahia coastal forest & $\begin{array}{c}109.123 \\
(8,1 / 99,8) \\
\end{array}$ & $\begin{array}{c}108.858 \\
(9,8 / 99,6) \\
\end{array}$ \\
\hline Atlantic Dry Forest & $\begin{array}{c}108.363 \\
(8,0 / 94,5)\end{array}$ & - \\
\hline Serra do Mar coastal forest & $\begin{array}{c}104.005 \\
(7,7 / 99,5)\end{array}$ & $\begin{array}{c}103.539 \\
(9,3 / 99,0)\end{array}$ \\
\hline Cerrado & $\begin{array}{c}103.893 \\
(7,7 / 5,5) \\
\end{array}$ & $\begin{array}{c}37.064 \\
(3,3 / 2,0) \\
\end{array}$ \\
\hline Uruguayan savana & $\begin{array}{c}35.611 \\
(2,6 / 10,1)\end{array}$ & $\begin{array}{c}15.376 \\
(1,4 / 4,4)\end{array}$ \\
\hline Caatinga & $\begin{array}{c}28.021 \\
(2,1 / 3,9)\end{array}$ & $\begin{array}{c}13.641 \\
(1,2 / 1,9)\end{array}$ \\
\hline Pernambuco interior forest & $\begin{array}{c}21.953 \\
(1,6 / 97,2)\end{array}$ & $\begin{array}{c}20.943 \\
(1,9 / 92,7)\end{array}$ \\
\hline Campos Rupestres montane savanna & $\begin{array}{c}20.040 \\
(1,5 / 81,3)\end{array}$ & $\begin{array}{c}17.059 \\
(1,5 / 69,2)\end{array}$ \\
\hline Pernambuco coastal forest & $\begin{array}{c}17.161 \\
(1,3 / 98,1)\end{array}$ & $\begin{array}{c}16.428 \\
(1,5 / 93,9) \\
\end{array}$ \\
\hline Southern Atlantic mangroves & $\begin{array}{c}9.476 \\
(0,7 / 97,6)\end{array}$ & $\begin{array}{c}9.046 \\
(0,8 / 93,2)\end{array}$ \\
\hline Atlantic Coast restingas & $\begin{array}{c}7.538 \\
(0,6 / 96,7)\end{array}$ & $\begin{array}{c}4.052 \\
(0,4 / 51,6)\end{array}$ \\
\hline Caatinga Enclaves moist forest & $\begin{array}{c}4.371 \\
(0,3 / 91,5)\end{array}$ & $x^{\circ}=0$ \\
\hline
\end{tabular}

*The values in parentheses represent the percentage of the Atlantic Forest in that ecoregion/and the percentage of the ecoregion within a given limit.

$$
\text { Source: Study data. }
$$

\section{DISCUSSION}

The two proposed limits for the Atlantic Forest, Domain and Biome, differ by $235,000 \mathrm{~km} 2$, that is, the Domain is about 20\% larger than the Biome. Divergent areas include physiognomies and biotas with characteristics of the Atlantic Forest strictu sensu, from the South and Southeast Regions (OLIVEIRAFILHO et al., 2006; BRAZIL, 2008), but also from transition areas with other biomes, such as the Cerrado and the Caatinga. The Atlantic Forest Domain (BRAZIL, 2008) encompasses most of the extra-Amazonian forest formations in Brazil (BRAZIL, 2004b).

Ab'Saber (2003) classified most of the incongruent areas between the two boundaries (Domain and Biome) as undifferentiated transition areas. They are composed by deciduous forests, steppe savannas, open and semi-deciduous forests, and transition zones between savannas and dry forests (BRAZIL, 
2004b). There are five major divergent regions between the two boundaries: (1) the São Francisco River Dry Forests; (2) Chapada Diamantina (Figure 2b); (3) the Northeastern Enclave Forests (Figure 2a); (4) the Plateau or Serra da Bodoquena (Figure 2c); and (5) the southern dry forests of Rio Grande do Sul and the surrounding of the Lagoa dos Patos (Figure $2 \mathrm{~d}$ ). The biotic composition reinforces the high heterogeneity, but also the similarity of Atlantic Forest characteristics, as well as the transitional aspects of these areas, as detailed below:

\section{SÃO FRANCISCO DRY FORESTS}

This region (Figure $2 \mathrm{~b}$ ) is composed of deciduous forests and patches of Cerrado and Caatinga, as well as zones of tension, contact, or transition between them (BRAZIL, 2004b; BRAZIL, 2008). In the first map of biodiversity hotspots (MYERS et al, 2000), this region was included in the Atlantic Forest, but not in the new map (MITTERMEIER et al., 2004).

Biotic inventories highlight the high occurrence of Caatinga endemic species (RODRIGUES, JUNCÁ, 2002; OLIVEIRA et al., 2003; PRADO, 2003; RODRIGUES, 2003). However, there are also endemic bird species from the Atlantic Forest (SILVA; CASTELETTI, 2003; LOPES et al., 2008) and other species typical from the dry forests of southeastern Brazil and from the Chapada Diamantina (KIRWAN et al., 2001). In the dry forests of Serra do Espinhaço, in the southern portion of this region, native bees (FARIA; SILVEIRA, 2011) and bats (SÁ-NETO; MARINHO-FILHO, 2013) common with other areas of the Atlantic Forest are found.

Evolutionarily, São Francisco's dry forests are key areas for the flow of forest biota, particularly considering the context of past and future climate change. During the Pleistocene climate fluctuations, the São Francisco River was a frontier area of the Atlantic Forest (CARNAVAL; MORITZ, 2008). The evolutionary history of the species that occurs in these transition areas still needs further study, but although they are important areas for Caatinga endemics, they also share the biodiversity of the Atlantic Forest, thus justifying their inclusion as Atlantic Forest. Therefore, the São Francisco Dry Forests are fundamental landscape units for the maintenance of the Caatinga biodiversity, but also of the Atlantic Forest.

\section{THE CHAPADA DIAMANTINA}

It is located between the dry forests of São Francisco and the coastal forests of Bahia (Figure 2b), inserted in the Caatinga Biome near the limits with the Atlantic Forest and Cerrado Biomes (BRAZIL, 2004a). It is a mosaic of deciduous, semideciduous forest formations and, to a lesser extent, patches of Montane and Savanna-Steppe Refuges (BRAZIL, 2004b). In the late Pleistocene, they formed a forest connection between the Amazon and Atlantic Forest (DE OLIVEIRA et al., 1999, CARNAVAL; MORITZ, 2008).

Phylogeographic studies indicate a greater connection between Chapada Diamantina and the Atlantic Forest (THOMÉ et al., 2016). The current fauna composition reflects the mosaic of phytophysiognomies present, resulting from the historical dynamics of biomes in this region. Small mammals typical from Cerrado, as well as from Caatinga and Atlantic Forest are found, occupying different types of habitat (PEREIRA; GEISE, 2007).

The most divergent population of a typical Caatinga lizard (Gymnodactylus gekonidae) occurs in this region (VANZOLINNI, 2004). New vertebrate species, more related to Southeast Atlantic Forest taxa, occur on the eastern slopes of this region (NAPOLI, JUNCÁ, 2006; RODRIGUES et al., 2006; GONZAGA et al., 2007). There are still some endemic fishes, exclusive of the eastern (coastal) basins of Brazil, in rivers of eastern Chapada (SANTOS, 2005). The composition of the biota on the eastern slopes of Chapada Diamantina appears to have a greater relationship with the Southeast Atlantic Forest, while the western slopes have a strong relationship with the Caatinga and Cerrado species. Therefore, it is also appropriate to consider this transition region as belonging to the Atlantic Forest. 


\section{THE NORTHEASTERN ENCLAVES}

The forest enclaves of northeastern Brazil, corresponding to the Caatinga Enclave Wet Forests ecoregion (Figure 2a), are "islands" of Open Ombrophilous Forest and Seasonal Semideciduous Forest surrounded by open Caatinga vegetation (BRAZIL, 2004b). The enclaves are found in different altitudes and geographical situations (PEREIRA, 2009). They are remnants of forest formations that occupied most of the Brazilian Northeast during the Quaternary climate oscillations (CARNAVAL; MORITZ, 2008), before the expansion of the caatingas (ANDRADE Lima 1982).

The flora of the lowland Northeastern forests is more similar to the Amazon forests (OLIVEIRA-FILHO et al., 2006), whereas in the hillside forests, plants are more related to the forests of the Southeast slopes (TABARELLI; CAVALCANTI, 2004). The occurrence and genetic structure of orchids corroborate the connection between the Enclaves and Atlantic Forest (PINHEIRO et al., 2014). On the other hand, the occurrence of typically Amazonian mammals, such as red-handled howler monkeys (Alouatta belzebul) and the pygmy anteater (Cyclops didactylus) (DE VIVO, 1997), in addition to the greater gene flow of the arboreal marsupial Marmosa (Micoureus) paraguayanus) (DIAS, 2007), indicate the biotic exchange between the Amazon and the Northeast forests.

The small mammals of the Enclaves are taxon of the Atlantic Forest and Caatinga (SOUSA et al., 2004), including species of bats typical from the Atlantic Forest (SILVA, 2007), and probably endemic species not yet studied (OLIVEIRA et al., 2003). The birds are endemic to the Caatinga, Atlantic Forest and other exclusive from forests of northeastern Brazil (RODA; CARLOS, 2004). Lizards are predominantly species with widespread distribution (42\%), as well as endemic (13\%), and others typically from the Atlantic Forest (10\%) and Amazon (8\%) (BORGES-NAJOSA; CARAMASCHI, 2003). The butterflies of the Pernambuco Center of Endemism have a great influence of species from Bahia, but also from the Belem Center of Endemism (BROWN, 1987).

Andrade-Lima (1982) points out that there is a gradient, a biogeographic cline, for the flora, where the Ceará Enclave forests are more related to the Amazon, while the Paraíba and Rio Grande do Norte Enclave have more elements from the Atlantic Forest. In Pernambuco and Paraíba, the enclaves include the Pernambuco (Coastal and Interior) and Caatinga (OLSON et al., 2001) Forests ecoregions, occupied by the Open Ombrophilous Forest and Steppe Savanna, as well as contact zones between these two physiognomies (BRAZIL, 2004a). In Ceará, the enclaves are classified in a separate ecoregion, the Caatinga Enclaves Moist Forests (OLSON et al., 2001), consisting of Open Ombrophilous Forest, and Cerrado and Caatinga contact zones with the Seasonal Forest (BRAZIL, 2004b). Therefore, the enclaves are not uniform regions regarding the composition and origin of the biota, they are typically transitional areas, with strong influence from the Atlantic Forest, the Amazon, the Cerrado, and the Caatinga biota. There is a longitudinal and altitudinal gradient, with the enclaves biota to the west and at low altitude more closely related to the Amazon, and those higher and to the east, more closely related to the Atlantic Forest.

\section{THE SERRA DA BODOQUENA}

It is located in the Midwest region of Brazil, in the Mato Grosso do Sul state (Figure 2c) in the Cerrado Biome's boundary with the Pantanal (BRAZIL, 2004a). Bird species in this region are mostly from the Cerrado and the Pantanal (Pivatto et al, 2006), but the occurrence of some species such as Synallaxis ruficaphilla, endemic to the Atlantic Forest (BRAZ, 2003), shows some common evolutionary history of these regions.

The composition of mastofauna has predominance of Cerrado species (CÁCERES et al., 2007). Diptera are typical of the Pantanal (GALATI, et al., 2003), and ants, probably more similar to the Cerrado fauna (SILVESTRE; DEMÉTRIO, 2007). The predominant physiognomy is of the contact between savanna (Cerrado) and Deciduous Seasonal Forest, as well as patches of Semidecidual and Cerrado Seasonal Forest (BRAZIL, 2004b). Therefore, it is appropriate to classify this region as a transition area of the Cerrado with elements of the Atlantic Forest. 


\section{DRY FORESTS AND MARSHES (BANHADOS) OF RIO GRANDE DO SUL}

The coastal region of southern Rio Grande do Sul around Lagoa dos Patos, and the dry forests of RS north central (Figure 2d) comprise a mosaic of distinct phytophysiognomies, with patches of seasonal semideciduous forest, steppes, restingas, peat forests and wetland (LEITE, 2002; BRAZIL 2004b; DORNELES; WAETCHER, 2004; BRAZIL 2008). The flora composition of RS is predominantly from Los Chacos, with xerophytic tropical, country or savanna elements (WAETCHER, 2002).

In the semideciduous forests of northern RS there is a predominance of shrubs from Atlantic origin (JARENKOW; WAETCHER, 2001). The forests in the northern limit of the Lagoa dos Patos are moderate semideciduous, with recent immigration of coastal (Atlantic) floristic flow over a resident continental seasonal flow, and still influenced by Amazonian elements (Leite, 2002). Thus, with increasing latitude, there is a gradual reduction of the Atlantic wooden components in the seasonal forests (MATTEl et al., 2007), as well as of the coastal epiphytes (WAETCHER, 1992).

Reptiles from southern RS are predominantly Pampean (QUINTELA et al., 2006), as are bats, with the influence of typical species from open formations (QUINTELA, et al., 2008). Above all, studies of biotic changes along the Holocene, over the last 10,000 years, indicate a gradual dynamic of expansion and shrinkage of rainforests, dry forests, and savannas in this region, and the previous presence of marsupials typical from areas of the southeast Atlantic Forest and dry forests of central Brazil (HADLER et al., 2009). Therefore, the biota of this region has a transitional character of the Atlantic Forest with the influence of phytophysiognomies of surrounding biomes.

\section{CLIMATE}

There is a complex climate diversification in the different regions that make up the Atlantic Forest, which directly influences the physiognomy and composition of the biota, and further hinders the accurate delimitation of such a wide and diverse biogeographic unit that encompasses the biodiversity of the Atlantic Forest. Above all, paleoclimatic models indicate that although there has been an intense history of expansions and retractions, the forest formations of what we call Atlantic Forest Domain have a common history (CARNAVAL; MORITZ, 2008; HADLER et al, 2009). Thus, although highly heterogeneous in biogeography and climate (NIEMER, 1979; CAVALCANTI et al., 2016), the areas of divergence between the two boundaries (Biome and Domain) are key part of the Atlantic Forest evolutionary history and for the flow of forest biota with other Brazilian biomes. Therefore, it is appropriate to consider the boundary of the Domain, or area of application of the Atlantic Forest Law, increasingly spreading the importance of the term Legal Atlantic Forest.

\section{LEGAL ATLANTIC FOREST: IMPLICATIONS FOR CONSERVATION}

The Atlantic Forest is a National Heritage, according to the Federal Constitution. The terms for their protection were defined by federal decrees no. 750/93, and n.6660/2008 and by the Atlantic Forest Law, Law n.11.428/08. This Law brings advances and represents an important legal framework, but uses the term "Atlantic Forest Biome", although the Map for the application of the Atlantic Forest Law Enforcement Area (BRAZIL, 2008) delimits the area of the Domain and not the Biome. Therefore, the nomenclature "Biome" used in the law brings some confusion to the practical applications of the law.

Proper interpretation and mapping of the legal Atlantic Forest is particularly important in daily life, for the application of public policies in licensing, inspection and incentives for protection and sustainable use on the ground, in the field (VASCONCELOS, 2014). Thus, it is important to pay attention to the implications of adopting the different limits (Biome and Domain). In addition, we must still consider the institutional precariousness summed to the advanced degree of biodiversity loss in the remaining forest fragments. 
The Atlantic Forest is home to $70 \%$ of endangered vertebrate species in Brazil, with more than one third of them being endemic species. Therefore, each remnant of the Atlantic Forest is strategic for maintaining biodiversity and associated environmental services. The existence of specific legislation brings an effective instrument for the implementation of practical measures for nature protection, despite the lack of human and financial resources and contrary interests by different sectors of society (LIMA, 2001). Thus, proper enforcement of the law is urgent within the entire area belongs to the Legal Atlantic Forest.

Special attention should be given to the northeast region, as this is where there is the largest difference, the largest additional portion of the Legal Atlantic Forest, when compared to the limit of the Biome (Figures 1 and 2 and Table 1). To make matters worse, the scarce remnants are small, severely depleted, isolated and unprotected fragments, particularly in the dry forests of the Northeast (SILVA; CASTELETTI, 2003; RIBEIRO et al., 2009; REZENDE et al., 2018). These areas have high species richness and endemism, besides encompassing extremes for the distribution of various taxon, and at the same time, they are the most devastated regions of the Atlantic Forest (OLIVEIRA-FILHO et al., 2006; RIBEIRO et al., 2009). The small network of protected areas further aggravates the conservation status or threat of these areas. Therefore, ensuring due compliance with the law within the limits of the Legal Atlantic Forest in northeastern Brazil is fundamental for the preservation of the biodiversity and environmental services of this biodiversity hotspot.

In addition to public policies, the effective use of human and financial resources, particularly at the state and municipal level, is urgently required for the conservation, restoration and promotion of sustainable use of their remnants. Local governments should encourage compliance with laws and regulations to control and encourage the protection of the Atlantic Forest (BRAZIL, 2006), as well as integration and synergies with other existing legislation, such as the new forest code, the Native Vegetation Protection Law, 12.727/2012. The role of states and municipalities is increasingly important, such as in the CARthe rural environmental registration (Cadastro Ambiental Rural), in designating areas and remnants to be protected as Legal Reserves and Permanent Preservation areas. As well as in the authorization and supervision of eventual vegetation suppression and environmental compensation and also the guidelines for the implementation of projects. Therefore, the presence of the state, with up-to-date and operational information systems, with trained and motivated personnel is fundamental for the environmental management of the Atlantic Forest, following all relevant legislation (VASCONCELOS, 2014).

Field integration and application also depends on mappings with adequate spatial resolution, preferably at 1:50,000 or 1:10,000 scale (e.g. VASCONCELOS, 2014; REZENDE et al, 2018). It is worth mentioning that the map of the Legal Atlantic Forest was elaborated in a scale of 1:5,000,000, it is an indicative limit, in simplified scale, and its application in the field depends on maps with adequate resolution and identification in loco (VASCONCELOS, 2014). The adequacy of these limits may lead to significant differences in areas considered as Legal Atlantic Forest or not, as in the case of Serra do Cipó (RIBEIRO et al., 2009b). Therefore, the delimitation of the Legal Atlantic Forest and its practical consequences still needs detailed mappings applied to the reality of the field.

\section{FINAL CONSIDERATIONS}

The Atlantic Forest encompasses ecosystems and assemblages of very heterogeneous species, as well as distinct climates. The biogeographic boundary is different for each taxon, with distinct evolutionary histories. In addition, forest remnants in the Atlantic Forest bordering areas are severely degraded and fragmented. Thus, the delimitation of a geopolitical or biogeographic unit is a complex and arbitrary but necessary task.

The two limits established for the Brazilian Atlantic Forest, Biome and Domain, differ as to the inclusion of extensive transition areas with other biomes, whose composition and biotic relationship are still poorly known. Considering that the composition and distribution of species in these transition 
areas is dynamic, on the evolutionary scale, and that there are frequent occurrence of taxons and physiognomies typical of the Atlantic Forest, the most appropriate limit, according to this study, is the Domain, or the Legal Atlantic Forest. Finally, the implementation of public policies for the conservation and sustainable use of biodiversity requires more detailed mapping, effective incentives, and stronger environmental agencies, particularly in northeastern Brazil.

\section{ACKNOWLEDGMENTS}

To A Paglia, C Padua, F Rodrigues, J Fragoso, JA Drummond and JL Andrade-Franco, and anonymous reviewers for the valuable contributions in preliminary versions of this work. To the faculty and students of PPECMVS of UFMG, where this work was carried out as part of the doctoral degree of A.A. Cunha, with CNPq scholarship and support from US Fish \& Wildlife Service, and from the Society for Conservation GIS - SCGIS. To the teams of the SPACE Lab, Dept. Geography, and the Vertebrate Lab., Dept. Ecology, from UFRJ; and UFMG Mastozoology, for the productive dialogues. To the support of the Conservation International of Brazil, Atlantic Forest team, at that time, LP Pinto, A Paglia, A Paese, I Lamas, and L Bedê. To several other researchers and authors, many cited in this paper, for references and exchanges of ideas about the biodiversity of the Atlantic Forest, and L Machado for the conversations about the climate.

\section{REFERENCES}

AB'SABER, A. N. Os domínios da natureza no Brasil: potencialidades paisagísticas. São Paulo: Ateliê Editorial, 2003.

BORGES-NOJOSA, D. M.; CARAMASCHI, U. Composição e análise comparativa da diversidade e das afinidades biogeográficas dos lagartos e anfisbenídeos (Squamata) dos Brejos Nordestinos. In: LEAL, I. R.; TABARELLI, M.; SILVA, J. C. M. (Org.). Ecologia e Conservação da Caatinga. Recife: Editora Universitária da UFPE, 2003. p. 463-512.

BRASIL. Mapa da Vegetação do Brasil. Instituto Brasileiro de Geografia e Estatística (IBGE), 1993. Rio de Janeiro, IBGE. 1993.

BRASIL. Mapa dos Biomas do Brasil. Instituto Brasileiro de Geografia e Estatística (IBGE), Rio de Janeiro, Brasil. 2004a.

BRASIL. Mapa da Vegetação do Brasil. Instituto Brasileiro de Geografia e Estatística (IBGE), Rio de Janeiro, Brasil. 2004b.

BRASIL. Lei n. 11.428, de 22 de dezembro de 2006: Lei da Mata Atlântica. Governo Federal, Brasília. 2006.

BRASIL. Mapa de Aplicação da Lei no 11.428/2006. Instituto Brasileiro de Geografia e Estatística (IBGE), Rio de Janeiro, Brasil. 2008.

BRAZ, V. da S. A representatividade das unidades de conservação do Cerrado na preservação da avifauna. Brasília, Tese (Doutorado em Biologia) - Universidade de Brasília, Brasília, 2003.

BROOKS, T. et al. Habiat loss and extinction in the hotspots of biodiversity. Conservation Biology, v. 16, p. 909-923, 2002.

BROWN, J. H. Concluding remarks. In: LOMOLINO, M. V.; HEANEY, L. R. (Org.). Frontiers of biogeography: new directions in the geography of nature. Sunderland, Sinauer Associates / International Biogeography Society. 2004. p. 361-368. 
BROWN, K. Biogeography and evolution of neotropical butterflies. In: WHITMORE T. C.; PRANCE, G. T. (Org.). Biogeography and quaternary history in tropical America. Oxford, Oxford University Press. 1987. p. 66-104.

CÁCERES, N. C. et al. Mammals of the Bodoquena Mountains, southwestern Brazil: an ecological and conservation analysis. Revista Brasileira de Zoologia, v. 24, p. 426-435, 2007.

CADASTRO NACIONAL DE UNIDADES DE CONSERVAÇÃO, 2019. Disponível em: <https://www.mma.gov.br/areasprotegidas/cadastro-nacional-de-ucs>. Acesso em: 17 jul. 2019.

CÂMARA, I. G. Brief history of conservation in the Atlantic forest. In: GALINDO-LEAL, C.; CÂMARA, I. G. (Org.). Atlantic Forest: biodiversity status, threats, and outlook. Washington, D.C., Island Press. 2003, p. 31-42.

CANALE, G. R. et al. Pervasive Defaunation of Forest Remnants in a Tropical Biodiversity Hotspot. PLoS ONE, v. 7, n. 8, p. e41671. 2012.

CARNAVAL, A. C.; MORITZ, C. Historical climate modelling predicts patterns of current biodiversity in the Brazilian Atlantic forest. J Biogeogr, v. 35, p. 1187-1201. 2008.

CAVALCANTI, I. et al. Tempo e Clima no Brasil. São Paulo. Oficina de Textos: 2016.

CRUZ, C. B. M.; VICENS, R. S. Levantamento da Cobertura Vegetal Nativa do Bioma Mata Atlântica. Relatório Final. PROBIO - Ministério do Meio Ambiente, Brasil. IESB/UFRJ/UFF, 2007.

CUNHA, A. A. Conservação dos Mamíferos na Serra dos Órgãos: passado, presente e futuro. In: IV CONGRESSO BRASILEIRO DE UNIDADES DE CONSERVAÇÃO, v. 1 - Trabalhos Técnicos 2004. Curitiba. Anais... FBPN, 2004, p. 213224.

CUNHA, A. A.; GUEDES, F. B. Mapeamentos para a conservação e recuperação da biodiversidade na Mata Atlântica: em busca de uma estratégia espacial integradora para orientar ações aplicadas. Brasília: Ministério do Meio Ambiente, 2013.

DIAS, I. M. G. Análise genética e fenotípica da população de Micoureus paraguayanus (Didelphimorphia: Didelphidade) no Parque Estadual do Rio Doce, MG. Tese (Doutorado em Genética) - Universidade Federal de Minas Gerais, 2007.

DORNELES, L. P. P.; WAECHTER, J. Fitossociologia do componente arbóreo na floresta turfosa do Parque Nacional da Lagoa do Peixe, Rio Grande do Sul, Brasil. Acta Botanica Brasilica, v. 18, p. 815-824. 2004.

FARIA, L. R. R.; SILVEIRA, F. A. A fauna de abelhas euglossinas (Hymenoptera, Apidae) em uma área central do Cerrado, Brasil: importância das florestas ripárias como corredores para espécies de abelhas associadas a florestas. Biota Neotrop. v. 11, p. 87-94. 2011.

FONSECA, C. R. et al. Towards an ecologically-sustainable forestry in the Atlantic Forest. Biological Conservation, v. 142, p. 1209-1219. 2009.

GALATI, E. A. B. et al. Phlebotomines (Diptera, Psychodidae) in caves of the Serra da Bodoquena, Mato Grosso do Sul State, Brazil. Revista Brasileira de Entomologia, v. 47, p. 283-296. 2003.

GALETTI, M. et al. Priority Areas for the conservation of Atlantic forest mammals. Biological Conservation, v. 142, p. 1229-1241. 2009.

GONZAGA, L. P.; CARVALHAES, A. M. P.; BUZZETTI, D. R. C. A new species of Formicivora antwren from the Chapada Diamantina, eastern Brazil (Aves: Passeriformes: Thamnophilidae). Zootaxa, v. 1.473, p. 25-44. 2007. 
HADLER, P. et al. Environmental change and marsupial assemblages in Holocene successions of Southern Brazil. Mammalian Biology, v. 74, p. 87-99. 2009.

HUECK, K. As florestas da América do Sul: ecologia, composição e importância econômica. São Paulo: Editora da Universidade de Brasília. 1972.

INSTITUTO BRASILEIRO DE GEOGRAFIA E ESTATíSTICA. Manual Técnico da Vegetação Brasileira. Série Manuais Técnicos em Geociências 1, 2a edição revista e ampliada. IBGE, Rio de Janeiro. 2012.

JARENKOW, J. A.; WAECHTER, J. E. Composição, estrutura e relações florísticas do componente arbóreo de uma floresta estacional no Rio Grande do Sul, Brasil. Revista Brasileira de Botânica, v. 24, p. 263-272. 2001.

KIRWAN, G. M.; BARNETT, J. M.; MINNS, J. Significant ornithological observations from the Rio São Francisco Valley, Minas Gerais, Brazil, with notes on conservation and biogeography. Ararajuba, v. 9, p. 145-161. 2001.

LARA, M. C.; GEISE, L.; SCHNEIDER, C. J. Diversification of small mammals in the Brazilian Atlantic forest of Brazil: testing the alternatives. In: LACEY, E. A.; MYERS, P. (Org.). Mammalian diversification: from chromosomes to phylogeography (a celebration of the career of James L. Patton). Berkeley: University of California Publications in Zoology. University of California Press, p. 311-335. 2005.

LEITE, P. F. Contribuição ao conhecimento fitoecológico do Sul do Brasil. Ciência \& Ambiente, v. 24, p. 51-73. 2002.

LIMA, A. Aspectos jurídicos da proteção da Mata Atlântica. (Org.). São Paulo: Instituto Socioambiental, 2001.

LIMA, D. A. Present day refuges in Norheastern Brazil. In: PRANCE, T. G. (Ed.). Biological diversification in the tropics. p. 245-254. New York, Columbia University Press. 1982.

LOPES, L. E. et al. Geographic distribution, habitat association, and conservation status of the Critically Endangered Minas Gerais Tyrannulet Phylloscartes roquettei. Bird Cons. Int., v. 18, p. 53-62. 2008.

MATTEI, G.; MULLER, S. C.; PORTO, M. L. Corredores de imigração e distribuição de espécies arbóreas no Rio Grande do Sul. Revista Brasileira de Biociências, v. 5, p. 12-14. 2007.

METZGER, J. P. et al. Time-lag responses to landscape changes in a highly dynamic Atlantic forest region. Biological Conservation, v. 142, p. 1166-1177. 2009.

MITTERMEIER, R. A. et al. Hotspots Revisited: earth's biologically richest and most endangered terrestrial ecoregions. Cidade do Mexico: CEMEX S.A. 2004.

MYERS, N. et al. Biodiversity hotspots for conservation priorities. Nature, v. 403, p. 853-858. 2000.

NAPOLI, M. F.; JUNCÁ, F. A. A new species of the Bokermannohyla circumdata group (Amphibia: Anura: Hylidae) from Chapada Diamantina, State of Bahia, Brazil. Zootaxa, v. 1244, p. 57-68. 2006.

NIMER, E. Climatologia do Brasil. IBGE, Rio de Janeiro, 1979.

OLIVEIRA FILHO, A. T.; JARENKOW, J. A.; RODAL, M. J. N. Floristic relationships of seasonally dry forests of eastern South America based on tree species distribution patterns. In: PENNINGTON, R. T.; LEWIS, G. P.; RATTER, J. A. (Org.). Neotropical savannas and dry forests: plant diversity, biogeography and conservation. Boca Raton: CRC Press. 2006. p. 151-184.

OLIVEIRA, J. A.; GONÇALVES, P. R.; BONVICINO, C. R. Mamíferos da Caatinga. In: LEAL, I. R.; TABARELLI, M.; SILVA, J. C. M. (Org.). Ecologia e Conservação da Caatinga. Recife: Editora Universitária da UFPE. 2003. 
OLIVEIRA, P. E. de, BARRETO, A. M. F.; SUGUIO, K. Late Pleistocene/Holocene climatic and vegetational history of the Brazilian caatinga: the fossil dunes of the middle São Francisco River. Palaeogeography, Palaeoclimatology, Palaeoecology, v. 152, p. 319-337. 1999.

OLSON, D. M. et al. Terrestrial ecoregions of the world: a new map of life on Earth. BioScience, v. 51, p. 933-938. 2001.

ORMSBY, T. et al. Getting to know ArcGIS desktop: basics of ArcView, ArcEditor, and Arclnfo. Redlands: ESRI Press. 2004.

PARDINI, R. et al. The challenge of maintaining Atlantic forest biodiversity: a multi-taxa conservation assessment of specialist and generalist species in an agro-forestry mosaic in southern Bahia. Biological Conservation, v. 142, p. 1178-1190. 2009.

PEREIRA, A. B. Mata Atlântica: uma abordagem geográfica. Nucleus, v. 6, p. 27-53. 2009.

PEREIRA, L. G.; GEISE, L. Karyotype composition of some rodents and marsupials from Chapada Diamantina (Bahia, Brasil). Brazilian Journal Biology, v. 67, p. 509-518. 2007.

PINHEIRO, F. et al. Rock outcrop orchids reveal the genetic connectivity and diversity of inselbergs of northeastern Brazil. BMC Evolutionary Biology, v. 14, p. 49, 2014.

PIVATTO, M. A. C. et al. Aves do Planalto da Bodoquena, estado de Mato Grosso do Sul (Brasil). Atualidades Ornitológicas, v. 129. 2006.

PRADO, D. E. As Caatingas da América do Sul. In: LEAL, I. R.; TABARELLI, M.; SILVA, J. C. M. (Org.) Ecologia e Conservação da Caatinga. Recife: Editora Universitária da UFPE. 2003. p. 3-74.

QUINTELA, F. M.; LOEBMANN, D.; GIANUCA, N. M. Répteis continentais do município de Rio Grande, Rio Grande do Sul, Brasil. Biociências, v. 14, p. 180-188. 2006.

QUINTELA, F. M.; PORCIÚNCULA, R. A.; PACHECO, S. M. Mammalia, Chiroptera, Vespertilionidae, Myotis albescens: new occurrence site in the state of Rio Grande do Sul, Brazil. Check List, v. 4, p. 79-81. 2008.

REZENDE, C. L. et al. From Hotspot to Hopespot: an opportunity for the brazilian atlantic forest. Perspectives in Ecology and Conservation, v.16, p. 208-221. 2018.

RIBEIRO, K. T. et al. Aferição dos limites da Mata Atlântica na Serra do Cipó, MG, Brasil, visando maior compreensão e proteção de um mosaico vegetacional fortemente ameaçado. Natureza \& Conservação, v. 7, p. 30-48. 2009.

RIBEIRO, M. C. et al. The Brazilian Atlantic Forest: how much is left, and how much is the remaining forest distributed? Implications for conservation. Biological Conservation, v. 142, p. 1141-1153. 2009a.

RIZZINI, C. T. Tratado de fitogeografia do Brasil. Aspectos ecológicos. São Paulo: Hucitec/Edusp. v. 2, 1979.

RODA, S. A.; CARLOS, C. J. Composição e sensitividade da avifauna dos Brejos de Altitude do Estado de Pernambuco. In: PORTO, K. C.; CABRAL, J. J. P.; TABARELLI, M. (Org.). Brejos de altitude em Pernambuco e Paraíba: história natural, ecologia e conservação. Brasília: Ministério do Meio Ambiente. 2004. p. 211-228.

RODRIGUES, M. T. Herpetofauna da Caatinga. In: LEAL, I. R.; TABARELLI, M.; SILVA, J. C. M. (Org.). Ecologia e Conservação da Caatinga. Recife: Editora Universitária da UFPE. 2003.

RODRIGUES, M. T.; JUNCÁ, F. A. Herpetofauna of the quaternary sand dunes of the middle Rio São Francisco: Bahia, Brazil. vii. Typhlops amoipira sp. nov., a possible relative of Typhlops yonenagae (serpentes, Typhlopidae). Papéis Avulsos de Zoologia, v. 42, p. 325-333, 2002. 
RODRIGUES, M. T. et al. A new species of lizard genus (Squamata, Leiosauridae) from the highlands of Chapada Diamantina, state of Bahia, Brazil, with a key to species. Phyllomedusa, v. 5, p. 11-24, 2006.

SÁ NETO, R. J.; MARINHO FILHO, J. Bats in fragments of xeric woodland caatinga in Brazilian semiarid. Journal of Arid Environments, v. 90, p. 88-94. 2013.

SANTOS, A. C. A. Peixes. In: ACUÑA, F.; JUNCÁ, L. F.; ROCHA, W. (Org.). Biodiversidade e Conservação da Chapada Diamantina. Brasília: Ministério do Meio Ambiente. p. 311-336, 2005.

SILVA, L. A. M. Comunidades de morcegos na Caatinga e Brejo de Altitude, no Agreste de Pernambuco. Tese (Doutorado em Biologia Animal) - Universidade de Brasília, Brasília, 2007. 161p.

SILVA, J. M. C.; CASTELETI, C. H. M. Status of the biodiversity of the Atlantic forest of Brazil. In: LEAL, C. G.; CÂMARA, I. G. (Org.) Atlantic Forest: biodiversity status, threats, and outlook. Washington, D.C.: Island Press. 2003. p. 43-59.

SILVESTRE, R.; DEMÉTRIO, M. F. Biogeografia e diversidade de formigas do Parque Nacional da Serra da Bodoquena, Mato Grosso do Sul. Biológico, v. 69, p. 225-227. 2007.

SOUSA, M. A. N.; LANGUTH, A.; AMARAL, E. G. Mamíferos dos Brejos de Altitude de Paraíba e Pernambuco. In: PORTO, K. C.; CABRAL, J. J. P.; TABARELLI, M. (Org). Brejos de altitude em Pernambuco e Paraíba: história natural, ecologia e conservação. Brasília: Ministério do Meio Ambiente. 2004. p. 211-228.

TABARELLI, M.; CAVALCANTI, D. R. Distribuição das plantas amazônico-nordestinas no centro de endemismo de Pernambuco: brejos de altitude vs. florestas de terras baixas. In: PORTO, K. C.; CABRAL, J. J. P.; TABARELLI, M. (Org). Brejos de altitude em Pernambuco e Paraíba: história natural, ecologia e conservação. Brasília: Ministério do Meio Ambiente. 2004. p. 279-290.

VANZOLINNI, P. E. On the geographical differentiation of Gymnodactylus geckoides SPIX, 1825 (Sauria, Gekkonidae): speciation in the Brazilian Caatingas. Anais Academia Brasileira de Ciências, v. 76, p. 663-698. 2004.

VASCONCELOS, V. V. Campos de Altitude, Campos Rupestres e Aplicação da Lei da Mata Atlântica: estudo prospectivo para o estado de Minas Gerais. Bol. geogr., Maringá, v. 32, p. 110-133. 2014.

VIEIRA, M. V. et al. Land use vs. fragment size and isolation as determinants of small mammal composition and richness in Atlantic Forest remnants. Biological Conservation, v. 142, p. 1191-2000. 2009.

VIVO, M. de. A mastofauna da Floresta Atlântica: padrões biogeográficos e implicações conservacionistas. In: V REUNIÃO ESPECIAL DA SBPC, 1997, Blumenau. Anais ... Blumenau. CNPq, 1997. p. 60-63.

WAETCHER, J. L. O epifitismo vascular na Planície Costeira do Rio Grande do Sul. Tese (Doutorado em Botânica) Universidade Federal de São Carlos. São Carlos, 1992. 163p.

Padrões geográficos na flora atual do Rio Grande do Sul. Ciência \& Ambiente, v. 24, p. 93-108. 2002. 